\title{
Analysis of the Advisability of Using Solar Collectors in a Single-Family House in Poland and Spain ${ }^{\dagger}$
}

\author{
Bernadetta Wądołowska * and Dorota Anna Krawczyk \\ HVAC Department, Bialystok University of Technology, 15-351 Bialystok, Poland; d.krawczyk@pb.edu.pl \\ * Correspondence: bernadettawadolowska@gmail.com; Tel.: +48-516-995-970 \\ † Presented at Innovations-Sustainability-Modernity-Openness Conference (ISMO'20), Bialystok, Poland, \\ 20-21 May 2020.
}

Published: 15 July 2020

\begin{abstract}
In this paper we show the advisability of usage of solar collectors for domestic hot water (DHW) preparation in buildings located in two countries: Poland and Spain. The analysis was conducted for a single-family house with horizontal roof. During the calculations we took into account factors depending on the building location such as national rules, climatic conditions, cost of system installation, and fuel and electricity prices. Based on the total design heat losses and demand for DHW, the demand for usable energy for heating the buildings and DHW preparation was calculated. A gas boiler was selected as the heat source of the building, and solar collectors (flat-plate and vacuum pipe) were chosen as the source of DHW preparation. Installation investment costs and annual operating costs have been stamped. Calculations show that for buildings located in Spain, heat losses were 36.5\% lower and the demand for thermal power for DHW was 59.5\% lower than for buildings located in Poland. Annual operating costs of the heating installation for both buildings were at similar levels, due to high fuel prices in Spain, while the operating costs of DHW installations were $28.2 \%$ higher for locations in Poland. The results show that the use of solar collectors in Poland is economically justified.
\end{abstract}

Keywords: solar collectors; renewable energy; heating; domestic hot water DHW

\section{Introduction}

Climate change is one of the biggest environmental, social, and economic threats. Global Climate Report for Annual 2019 [1] shows that in recent years changes progressed much faster than before. One of the main reasons for such a drastic temperature increase is the use of fossil fuels for energy production. Burning coal, oil, or gas causes greenhouse gas emission to the atmosphere, which significantly increases the average global temperature. Due to this growing problem, the focus in recent years has been on the search for alternatives to traditional fossil fuels. One of the ways to combat global warming is to use renewable energy sources (RES). The role of RES in environmental protection has been previously discussed [2,3].

The biggest advantage of RES is their availability. Solar energy is particularly outstanding in this respect, such that we more or less have access to it anywhere on Earth. Low-carbon investments that significantly reduce environmental pollution also lead to improved quality of life. Energy produced from renewable sources also affects the development of many sectors of the economy. It contributes to the growth of innovation and causes the labor market to expand.

In addition to ecological and economic reasons, in the European Union there are also many restrictions that require the use of RES. As at 23 April, 2009 the European Parliament have adopted a directive on the promotion of the use of energy from renewable sources [4]. This directive was one of the most ambitious and restrictive renewable energy policies in the world. European Union member 
states have committed to themselves that by 2020 and 2030 at least $20 \%$ and $32 \%$, respectively, of total energy needs in European Union will be fulfilled by renewable energy.

\section{Methodology}

The analysis was conducted for a single-family house. We considered two locations: Madrid in Spain and Warsaw in Poland. Both locations were in the average zone. The analysis was based on a comparison of the total design heat losses, demand for thermal power for domestic hot water, demand for usable energy for heating and hot water, investment costs of installations divided into installations with flat-plate and vacuum pipe collectors, and annual operating costs of installations. Coefficients of heat transfer through building partitions were adopted as the maximum acceptable in Poland, but also meeting the requirements in Spain. The consumption of hot water by the inhabitant during the day was determined in accordance with the guidelines assuming $65 \mathrm{dm} / \mathrm{M} \cdot \mathrm{d}[5]$ in Poland and $28 \mathrm{dm}^{3} / \mathrm{M} \cdot \mathrm{d}$ in Spain [6]. Solar collectors for the optimal tilt angle were selected using Virtual and Intensive Course Developing Practical Skills of Future Engineers (VIPSKILLS) tools (prepared during Virtual and Intensive Course Developing Practical Skills of Future Engineers Project implemented as a part of the Erasmus+ program, project reference: 2016-1-PL01-KA203-026152).

\section{Results and Discussion}

The calculations show that the overall design heat losses for a building located in Poland was $11.8 \mathrm{~kW}$ and for s building located in Spain it was $7.5 \mathrm{~kW}$. Higher losses in Poland result from the indoor and outdoor temperatures adopted in accordance with the design guidelines.

The demand for thermal power for domestic hot water for a building located in Poland was 7.46 $\mathrm{kW}$, while for a building located in Spain it was $3.02 \mathrm{~kW}$. This is primarily due to the resident's consumption of hot water in the day. In Poland, the assumed water consumption was more than twice as high as the consumption in Spain.

Regarding the demand for useable energy for heating the building and preparing hot water (Figure 1), in both cases, higher values occurred in buildings located in Warsaw. With regard to heating, it mainly depended on the overall design heat losses and also the number of heating degree days (HDD), which was 3944 in Warsaw and 2931 in Madrid. In case of demand for usable energy for domestic hot water (DHW) preparation, the difference in demand was primarily due to the amount of water consumed per-year by the inhabitant, as well as the difference between the temperature of the cold water flowing into the installation. In Warsaw the cold water temperature was $10^{\circ} \mathrm{C}$, while in Madrid it was $13^{\circ} \mathrm{C}$.

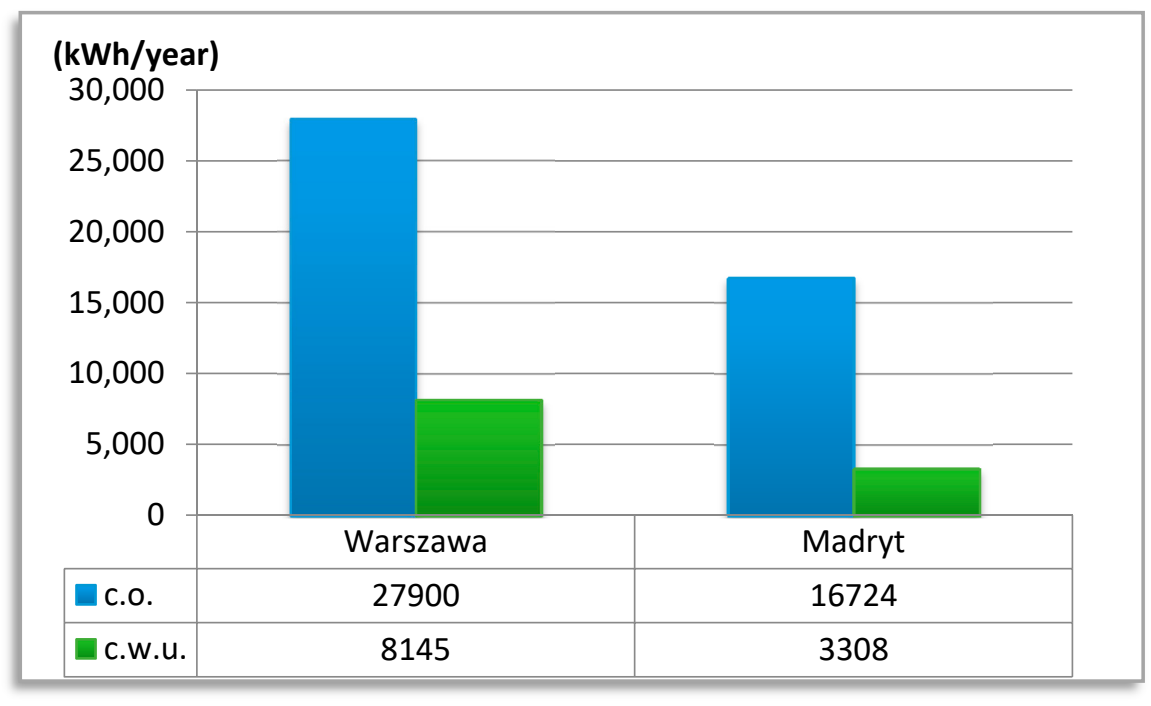

Figure 1. Demand for usable energy for heating and domestic hot water (DHW) preparation in Poland and Spain (based on [7]). 
For the solar collector calculations, the tilt angle adopted was $42^{\circ}$ for Warsaw and $34^{\circ}$ for Madrid. For heating DHW in Warsaw three flat-plate and four vacuum pipe collectors were selected. For the building located in Madrid one flat-plate and one vacuum pipe collector was selected.

Comparing installations of flat-plate and vacuum pipe collectors, higher investment outlays in both Warsaw and Madrid incur for vacuum pipe collectors (Figure 2). In this case, a particularly large difference was noticeable for a building located in Poland. This is mainly due to the larger number of collectors adopted, as well as the higher purchase prices for this type of installation.

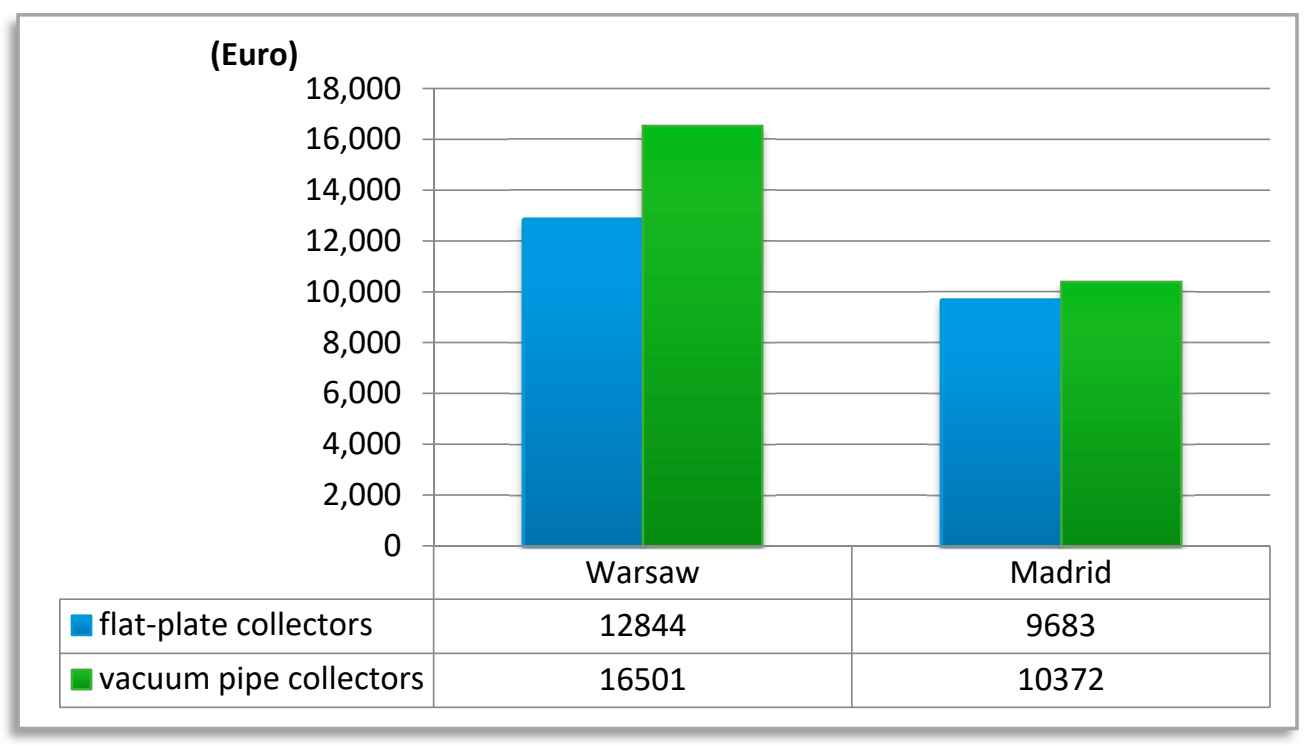

Figure 2. Investment outlays for heating and DHW installations in Poland and Spain (based on [8]).

As shown in Figure 3, the annual operating costs of installations were higher for a building located in Warsaw. The annual cost of heating a building with a gas boiler does not differ depending on the location, despite the fact that the demand for heating energy for the building in Poland was much higher. This is due to the difference in price for $1 \mathrm{kWh}$ of gas consumption. The gas price in Spain is $70 \%$ higher than in Poland. The same applies to the annual operating costs of DHW installations. In Warsaw, they are slightly higher than in Madrid despite the fact that the demand for energy for locations in Poland was about $60 \%$ higher. This is also due to the difference in the price for electricity, which is almost twice as high in Spain than in Poland.

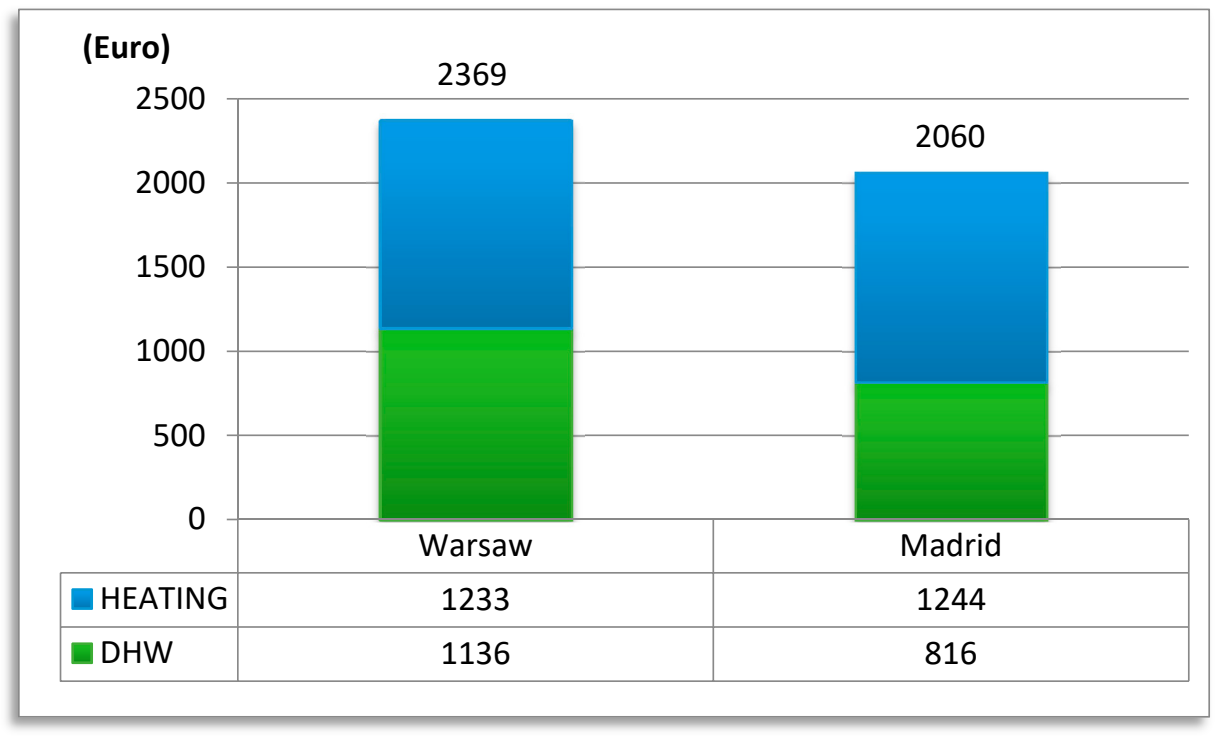

Figure 3. Annual operating costs of heating and DHW preparation in Poland and Spain (based on [8]). 


\section{Conclusions}

Based on the results obtained, it can be stated that solar collectors are more economically advantageous in Spain than in Poland. This is primarily due to climatic conditions. Higher temperatures and much more sunshine hours per-year result in solar collectors and solar installations achieving higher efficiency, which means the system generates lower energy consumption and lower costs. It should also be noted that traditional fuel prices in Spain are very high. For this reason, investing in renewable energy sources is becoming the best alternative.

In Poland, investment outlays and annual operating costs are higher than in Spain, but this does not mean that the solar installation in Polish climatic conditions is unprofitable. Appropriate design of the installation and correct operation mean that the one-off costs of purchasing solar collectors pay for themselves as a result of the savings obtained by reducing the use of traditional fuels.

Author Contributions: B.W. and D.A.K. conceived and designed the experiments; B.W. performed the experiments and analyzed the data; D.A.K. contributed analysis tools; B.W. and D.A.K. wrote the paper. All authors have read and agreed to the published version of the manuscript.

Conflicts of Interest: The authors declare no conflict of interest.

\section{References}

1. NOAA National Centers for Environmental Information, State of the Climate. Global Climate Report for Annual 2019. 2020. Available online: https://www.ncdc.noaa.gov/sotc/global/201913 (accessed on 4 March 2020).

2. Panwar, N.L.; Kaushik, S.C.; Kothari, S. Role of renewable energy sources in environmental protection: A review. Renew. Sustain. Energy Rev. 2011, 15, 1513-1524, doi:10.1016/j.rser.2010.11.037.

3. de Llano-Paz, F.; Calvo-Silvosa, A.; Iglesias Antelo, S.; Soares, I. The European low-carbon mix for 2030: The role of renewable energy sources in an environmentally and socially efficient approach. Renew. Sustain. Energy Rev. 2015, 48, 49-61, doi:10.1016/j.rser.2015.03.032.

4. Directive 2009/28/EC of the European Parliament and of the Council of 23 April 2009 on the Promotion of the Use of Energy from Renewable Sources. Available online: https://eur-lex.europa.eu/eli/dir/2009/28/oj (accessed on 4 March 2020)

5. Regulation of the Minister for Infrastructure. Regarding the Determination of Average Water Consumption Standards; Dz.U.2020.8.70, Warszawa, 2002. (In Polish)

6. HE 4 Contribución Solar Mínima de Agua Caliente Sanitaria. In Documento Básico HE Ahorro de Energía; Ministerio de Fomento: Madrid, Spain, 2017.

7. VIPSKILLS tools [2016-1-PL01-KA203-026152] prepared during Virtual and Intensive Course Developing Practical Skills of Future Engineers Project implemented as a part of the Erasmus+ program.

8. Wądołowska, B. Analysis of the Advisability of Using Solar Collectors in a Single Family House in Poland and Spain. Master's Thesis, Bialystok University of Technology, Białystok, Poland, 2019.

(c) 2020 by the authors. Licensee MDPI, Basel, Switzerland. This article is an open access article distributed under the terms and conditions of the Creative Commons Attribution (CC BY) license (http://creativecommons.org/licenses/by/4.0/). 